\title{
Study on the Risk and Prevention of Accounting Files Computer Management
}

\author{
Biao Liu ${ }^{1, a}$ \\ ${ }^{1}$ Jiangxi Science \& Technology Normal University, Finance Department, Nanchang, Jiangxi, \\ 330013 \\ ${ }^{a}$ email
}

Keywords: Accounting Files, Computer Management, Risk and Prevention

\begin{abstract}
With the current social science and technology innovation and in-depth technology, computer technology in various industries gradually been widely used, accounting computer file management are also beginning to become an important development direction of contemporary society in accounting work. However, the use of computer technology to the management of accounting files, although the efficiency of accounting work can make a large extent improved, but at the same time will also bring the accounting information distortion and other issues, especially the accounting records of the existence of computer management risk issues. By analyzing the risk of computer management accounting files that exist in the present, and the corresponding risk prevention measures on this basis, hoping to bring some help for our security and accounting archives computer management efficiencies.
\end{abstract}

\section{Introduction}

As science and technology continues to evolve and progress of computer technology gradually began to spread. The use of computer technology to the management of accounting files, it is possible to enhance the efficiency of the accounting records management work to a large extent, the accounting work carried out has a very important role. However, with the use of computer and more time in the accounting work, a lot of problems have gradually emerged, which was to bring about the most major accounting data there are certain risks. Therefore, only accounting for risk management in the computer file exists for effective prevention, in order to promote the role of computer technology in the accounting field in full play, so as to further enhance the overall efficiency of the accounting work.

\section{Risk Accounting File Computer Management}

Basis for accounting archives computer management is the need for appropriate support software and hardware system, and therefore, with the continuous development of science and technology, and greatly affected the accounting archives computer management process. Treat information technology development faster and faster, which is beneficial in helping to bring the accounting archives information resources management and development process, also to the accounting archives management of our time brought a lot of technical risk. First, with the accelerating pace of development of science and technology, but also in a certain extent, increased the number of accounting records information storage medium, the storage-related software is gradually increasing, but no matter which type of accounting records management software, the current and words, lack of vouchers Annex data storage capacity, in simple terms, is in computer management, accounting data accounting records and related accessories information exist independently of each other, which will make the accounting records computer management technical operational risk becomes greater, in the process of verification of the accounting records, the time spent also will increase a lot [1]. Secondly, in the development of modern technology faster and faster background, file management accounting software update speed faster and faster, so it must be relevant to the needs of the entity and financial management software system, constantly updated, we want to achieve this point the unit will need to give some financial support. But the financial management of 
equipment upgrades too fast, it needs to be updated frequently and, thus prompting financial management costs increase a lot, and then there are also some units do not want the system and software up to date. When this happens, the latest technology will promote electronic financial management can not be effectively used, resulting in computer accounting records management processes and effects severely affected.

In the background of the current information age, the Internet and computer technology is the main direction of basic accounting records management for future development, but at the same time is the main factor causing information security risks. Accounting archives computer management process, the main information security risks facing three aspects: First, the accounting records information modify risk. Electronic data management computer accounting files generated during the information is very vulnerable to changes away also has some hidden, which means the security of accounting information file a direct effect [2]. Secondly, the accounting archives information leakage risks. Although today's network technology is very mature, but the associated safety precautions are still many loopholes still exist, for example: no access to LAN users do inside and outside the scientific setting, there is no firewall timely updates are very likely will lead the entire computer system to fail and, thus, to some unscrupulous hacker brought a lot of convenience, in turn resulting in significant accounting records information leakage problem. Finally, save the problem of accounting archives information. Accounting archives information need to rely on computer storage media to save, but if the problem related to the storage device is damaged, aging and the failure or the like, will cause the loss of accounting records information.

\section{Risk Precautions of Accounting Files Computer Management}

Compared with traditional paper records management, the cost is bound to increase computer accounting records management a lot, but the advantage is the ability to make efficiency has been improved accounting records, accounting records so that information resources can be shared participation rate in many fields become more quickly, thus contributing to the accounting records is becoming an economic resource, serving the development of society as a whole [3]. Therefore, China's relevant units should be changed the traditional concept of the importance of accounting records managed computers do well recognized in the annual financial budget, launch special funds to promote computer management accounting files for advanced software and financial accounting the introduction of the system has brought strong economic security. Based on this, the relevant units should be calculated on the development and use OCR will be continuously strengthened, prompting previous accounting separation of accounting files and data information between the original document attachments are effectively eliminated. OCR technology mainly refers to optical character recognition [4]. This technique through video input, image pre-processing, text feature extraction, matching identification, manual calibration and input to save recognition results to complete the accounting archives management. This technology not only allows the input of accounting records to enhance efficiency, but also can be saved in the computer accounting information of the original material, so that accounting records accounting data and information on the original certificate Annex unified storage can be truly realized.

Implementation of accounting archives computer management needs to have more high-quality accounting records management staff, but from the structure in terms of the quality of accounting records management staff of the moment, mostly professional staff in finance, accounting and records management, and computer professional staff the very small, from a certain point of view in terms of, this is one of the main causes of information security risks. While many places in China are beginning to present extensive use of computerized accounting records management, but due to lack of professional personnel, most accounting archives simply use the computer catalog management, computer management and accounting records have not been truly realized. Between this, the relevant units of the gradual introduction of computer professionals, so staff have to be a computer professional accounting archives management. Only quality structure of accounting records management staff to effectively improve, so to make the moment of connection problems between computer technology and file management that exists effectively eliminate [5]. It should 
also focus on training of accounting personnel file management quality, by means of regular training and performance appraisal and other means to promote awareness of security accounting archives management has been strengthened, then the computer will be able to make accounting records management process of a number of risks and safety risks are effectively mitigated.

First, the access control to the application of technology related to access control has been strengthened to ensure that network access accounting records information system, the network port authority and other security to obtain effective control. Can by means of the use of technology for user authentication and encryption key management technology to prevent access of unauthorized persons. Secondly, in terms of virus protection, the relevant units should be detailed to antivirus programs worked out, and antivirus software installed and updated in a timely manner to prevent the virus invasion of accounting records. Finally, in the process of accounting data file backup, electronic accounting records should strictly implement dual backup system [6]. Electronic accounting file double backup systems were developed and implemented, which can only be a certain control and verification, strict means to prevent the use of external copy, so as to promote the raw accounting data files are protected; and then let another as read-only file, you can read and view but not modify, thereby allowing illegal intrusions into computer illness accounting information file modification phenomenon has been effectively prevented.

\section{Conclusion}

All in all, the current rapid development of computer technology, promote the traditional paper accounting files has been greatly changed, but the use of computer management accounting files even though it can improve efficiency, but there are also many risks. Therefore, only the accounting archives computer management and effective risk prevention, so in order to make the computer technology in the accounting records management role into full play.

\section{References}

[1] Xie Junping. Risk and Prevention accounting records electronic management of [J] Lantai world, 2015, 17: 45-46.

[2] Han Dongmei. College Accounting Archives Management Prevention [J]. Lantai world, 2012, 32: 64-65.

[3] Jiang Hui. Risk and Prevention era of computerized accounting computer system [J]. Market Modernization, 2011, 14: 140.

[4] Zhang Jinliang. On Strengthening the Management of Electronic Archives significance and risk prevention measures [J]. Heilongjiang Science and Technology Information, 2016, 06: 156.

[5] Gao Taiping. high risk and prevention measures exist in electronic accounting [J]. Economist, 2013,01: 195-196.

[6] Wang Beiyan. focus of hospital management accounting and financial risk prevention [J]. Business (Finance and Economics), 2012,03: 54. 